\author{
MACIEJ KŁODAWSKI \\ ORCID: 0000-0001-9011-3620 \\ Uniwersytet Szczeciński
}

\title{
LEGISLATORZY W PUŁAPCE POLITYCZNOŚCI
}

\begin{abstract}
Abstrakt: W artykule dokonano analizy statusu i roli legislatorów przez pryzmat zaczerpniętej od Chantal Mouffe kategorii polityczności. Punktem szczególnego zainteresowania w przeprowadzonym wywodzie uczyniono relację między legislatorami a prawodawcą, wpływ polityczności na pozycję i możliwe działania legislatorów w procesie legislacyjnym oraz zdolność legislatorów do opierania się siłom polityczności występującym w całym procesie prawodawczym. Polski system tworzenia prawa wykorzystano w pracy jako przykład ukazujący, które czynniki i okoliczności, mające podłoże polityczne, pociągają za sobą konstrukcję tak zwanej pułapki polityczności dla legislatorów. Główną tezą przedstawioną w artykule jest stwierdzenie, że podatność legislatorów na wpływ sił polityczności pozostaje poza ich kontrolą, w przeciwieństwie do reprezentantów prawodawcy, mimo że legislatorzy także są uczestnikami wielu etapów tworzenia prawa.
\end{abstract}

Słowa kluczowe: legislator, ekspert legislacyjny, legislacja, tworzenie prawa, polityczność

\section{WPROWADZENIE}

Nie ulega wątpliwości, że tworzenie prawa jest procesem mającym, oprócz oczywistego wymiaru prawnego, wymiar polityczny. Mimo to wielu przedstawicieli prawoznawstwa zdaje się odsuwać w cień namysł nad tym, w jaki sposób mechanizmy i oddziaływania polityczne biorą udział w tworzeniu prawa. Jest to wyraźnie zauważalne już $\mathrm{w}$ odniesieniu do sposobu pojmowania prawodawcy jako bytu nie tylko jednostkowego, lecz w dodatku wyposażonego w narzędzia i mającego cechy dalekie od politycznej niedoskonałości.

Koncepcja prawodawcy racjonalnego przez długi czas była zasadniczym przedmiotem zainteresowania polskich teoretyków legislacji. W tak zorientowanym spojrzeniu nie zawsze znajdowało się miejsce na wnikliwą analizę rzeczywistych zjawisk i relacji występujących między politycznymi decydentami a prawnikami wspomagającymi tych decydentów w przekuwaniu podjętych decyzji na prawo, a ściślej — na przepisy prawne. Dopiero narastająca liczba błędów o rozmaitej naturze w tekstach 
aktów normatywnych ${ }^{1}$, których nie sposób wytłumaczyć poprzez sięgnięcie do konstruktu racjonalnego prawodawcy, skierowała uwagę badaczy prowadzących swe rozważania na gruncie teorii prawa na prawodawcę faktycznego ${ }^{2}$ i współdziałających z nim ekspertów ${ }^{3}$.

Z czasem z grona ekspertów zaczęto wyodrębniać legislatorów jako tych prawników, którzy najbliżej i najczęściej, bo przy uchwalaniu albo ustanawianiu właściwie każdego aktu normatywnego, mają okazję i obowiązek współpracować z decydentami politycznymi. Przedstawiano przy tym wymagające przekrojowego, szerokiego spojrzenia i interdyscyplinarnej wiedzy rozważania poświęcone statusowi zawodowemu, roli społecznej i etyce legislatora czy jego odpowiedzialności karnej w procesie tworzenia prawa, a także uwagi skupiające się na problemach cząstkowych, takich jak na przykład legislatorska przezorność czy antycypacja.

Niniejszy tekst wpisuje się w ten nurt badań prawoznawczych, których obiektem są legislatorzy. W artykule zostaje podjęta próba zgłębienia, w jaki sposób i do jakiego stopnia relacje między wybranymi aktorami procesu legislacyjnego $\mathrm{w}$ polskim porządku prawnym, to jest prawodawcą faktycznym a legislatorami, są determinowane przez politykę ukształtowaną przez czynnik polityczności. Żaden prawnik, a legislator — z już zasygnalizowanych względów — w szczególności, nie może zapominać o politycznych konsekwencjach swojej profesji, gdyż świat prawa i świat polityki nie są od siebie odseparowane ${ }^{4}$. Choć nie każda norma prawna wiąże się z wymiarem polityczności ${ }^{5}$, to często dotychczas obserwowane przeciwstawianie problematyki prawnej i politycznej może uchodzić per se za pewnego typu rozstrzygnięcie polityczne, które w niektórych obszarach może prowadzić nie tylko do zawężenia warstwy pojęciowej dyskursu, lecz także do zubożenia zasobu wykorzystywanych w nim argumentów 6 .

Celem artykułu jest sprawdzenie trafności hipotezy, zgodnie z którą legislatorzy wbrew zadeklarowanemu zakresowi podejmowanych działań w ramach spełniania obowiązków, do których są nominalnie powołani, zostają zaangażowani nie tylko w kształtowanie polityk publicznych (public policies), ale też włączeni w poczet osób, wobec których zwraca się polityczność w związku z polityką partyjną (party

1 Zob. A. Malinowski, Btędy formalne w tekstach prawnych, Warszawa 2020.

2 Zob. np. A. Borowicz, Argument interpretacyjny odwolujacy się do woli rzeczywistego prawodawcy, „Studia Prawno-Ekonomiczne” 79, 2009, s. 9-28; A. Bielska-Brodziak, Śladami prawodawcy faktycznego. Materiały legislacyjne jako narzędzie wykładni prawa, Warszawa 2017, passim.

${ }^{3}$ Literatura w tym zakresie jest bardzo obszerna. Jej przegląd przedstawia A. Bielska-Brodziak (eadem, op. cit., s. 246, przyp. 355). Zob. też Z. Radwański, Rola prawników w tworzeniu prawa, „Państwo i Prawo" 1994, nr 3.

${ }^{4}$ Por. M. Paździora, M. Stambulski, Co może dać nauce prawa polityczność? Przyczynek do przyszłych badań, „Archiwum Filozofii Prawa i Filozofii Społecznej” 2014, nr 1, s. 65.

5 Por. R. Mańko, Orzekanie w polu polityczności, „Filozofia Publicznai Edukacja Demokratyczna” 7, 2018, nr 1, s. 73.

${ }^{6}$ Według M. Paździory i M. Stambulskiego ,[t]wierdzenie, że polityczność nie jest konstytutywna dla dyskursu prawniczego jest już liberalnym rozstrzygnięciem politycznym" - eidem, op. cit., s. 58. 
politics $)^{7}$. Wiąże się to z przypuszczeniem co do istnienia „pułapki polityczności”, która w wypadku legislatorów oznacza, że skoro wraz ze zmianą ustroju zostali oni włączeni, a w każdym razie zbliżeni, do pola funkcjonowania polityczności i polityki, to mogą opuścić tę sferę dopiero wskutek ingerencji nadrzędnego wobec legislatorów podmiotu należącego do legislatywy.

Dodatkowym celem opracowania jest dostarczenie i analiza argumentów pozwalających wykazać trafność drugiej hipotezy, że kształtowanie w procesie legislacyjnym statusu i roli legislatora następuje głównie przez oddziaływanie zjawisk i mechanizmów właściwych polityczności, takich jak działania nieoficjalne, instrumentalne wykorzystywanie dysproporcji potencjałów decyzyjnych, tworzenie bądź umacnianie napięcia lub konfliktu, a nie przez prawne czy inne w jakikolwiek sposób sformalizowane i uchwytne środki wpływu.

Niniejszy tekst składa się z sześciu części. Oprócz bieżącej części o charakterze wstępnym wyróżniono część drugą, w której przedstawiono uwagi na temat znaczenia pojęć „,polityczność”, „polityka” i „legislator”, zwłaszcza w kontekście procesu tworzenia prawa, w którym odgrywają istotną rolę. Część trzecia zawiera uwagi o relacjach między prawodawcą faktycznym a legislatorami, ponieważ jako znacząca przedstawia się potrzeba udzielenia odpowiedzi na pytanie o umiejscowienie legislatorów - w konstrukcie prawodawcy czy poza nim? W czwartej części analizowane są kierunki oddziaływań między zjawiskiem polityczności a legislatorami. Część piąta zawiera diagnozę możliwości opierania się legislatorów wpływowi polityczności oraz wskazuje niedobór tych możliwości wraz z analizą przyczyn tego stanu i ewentualnymi możliwościami jego zmiany. W ostatniej, szóstej, części zawarto uwagi podsumowujące.

\section{SIATKA POJĘCIOWA — „LEGISLATOR” A „POLITYCZNOŚĆ” I „POLITYKA”}

Analizując klasyczną już pracę przybliżającą studentom prawa zagadnienia teoretycznoprawne ${ }^{8}$, Michał Paździora i Michał Stambulski zauważają, że według jej autorów ,[t]wworzenie prawa jest działalnością polityczną, lecz w momencie powstania normy prawnej genetyczna polityczność takiej normy zostaje tajemniczo zapomniana", a więc ostatecznie „[ś]wiat prawa i świat polityki są od siebie odseparowane" ${ }^{10}$. Już choćby krótkie i przygodne uczestnictwo w faktycznie przebiegającym procesie legislacyjnym pozwala jednak ukazać daleko posuniętą nieprzystawalność takiego poglądu — nawet gdyby uznać, że w parafrazie Paździory i Stambulskiego

\footnotetext{
7 O znaczeniu pojęć „polityki publiczne” i „polityka partyjna” zob. R. Mańko, op. cit., s. 69-70.

8 Chodzi o pracę S. Wronkowska, Z. Ziembiński, Zarys teorii prawa, Poznań 2001.

9 M. Paździora, M. Stambulski, op. cit., s. 65.

10 Ibidem.
} 
został on w jakiś sposób uproszczony czy przejaskrawiony ${ }^{11}$ — do rzeczywistości, w której tworzone są przepisy prawne. Dlatego też badacze poświęcający się zgłębianiu arkanów rzeczywiście zachodzącego procesu prawotwórczego i formułujący respektujące je teorie legislacji, którzy tracą z pola widzenia aspekt polityczny stanowienia prawa, często uszczuplają lub nadwątlają zasób założeń i argumentów pozwalających na wyczerpujące i przekonujące uzasadnienie swoich koncepcji.

Zainteresowanie prawodawcą faktycznym, zadeklarowane już we wstępie, w naturalny sposób prowadzi do pogłębienia namysłu nad sferą polityki i polityczności. $\mathrm{Z}$ tego względu, a także $\mathrm{z}$ uwagi na chęć możliwie jasnego przedstawienia pojęć o zasadniczym znaczeniu dla prowadzonego tu wywodu, konieczne jest wyjaśnienie „polityczności” i „polityki”. W niniejszym opracowaniu przyjęty został sposób rozumienia wspomnianych dwóch pojęć zaczerpnięty od Chantal Mouffe - wykorzystywany także w wielu innych opracowaniach o teoretycznoprawnym lub filozoficznoprawnym ukierunkowaniu ${ }^{12}$ — bez wchodzenia jednak w meandry postrukturalistycznego dyskursu. Pracy tej towarzyszy przekonanie, że polityczność to „wymiar antagonizmu leżący u podstaw każdego ludzkiego społeczeństwa”"13, podczas gdy polityka to ,zestaw praktyk i instrukcji, które w obliczu wprowadzonego przez polityczność konfliktu tworzą porządek umożliwiający ludzkie współistnienie"14. Przywołane definicje w kontekście tematyki niniejszego opracowania uzupełnia twierdzenie Paździory i Stambulskiego, że ,[n]ie każdy podmiot jest prawnikiem czy politykiem, lecz każdy posiada jakąś tożsamość, której treść powstaje w oparciu o rozstrzygnięcia na poziomie polityczności”'15. Uważna obserwacja praktyki tworzenia prawa potwierdza bowiem trafność tego spostrzeżenia w odniesieniu do legislatorów, wobec których roli i statusu zawodowego skierowane są opisywane w dalszej części tekstu oddziaływania polityczne i ich skutki. Jednocześnie ten kontekst refleksji teoretycznej nad miejscem i funkcją legislatorów w systemie tworzenia prawa, zwłaszcza polskim, zasługuje na wyeksponowanie z uwagi na dotychczasową relatywnie skąpą reprezentację w rodzimej literaturze z zakresu prawoznawstwa.

11 Inaczej przedstawia się bowiem, wprawdzie nieco później wyrażony, pogląd Sławomiry Wronkowskiej, zgodnie z którym proces prawodawczy „ma charakter polityczny w tym sensie, że decyzje o celach regulacji prawnych, ustanowieniu norm, ich treści i czasie ich wprowadzenia w życie podejmują instytucje sprawujące władzę. Wpływ na ten proces ma całe społeczne, kulturowe $\mathrm{i}$ intelektualne otoczenie, zwłaszcza rozpowszechnione wartości, tradycja, obyczaje w życiu publicznym, kultura polityczna i prawna oraz wiedza elit podejmujących decyzje" - eadem, Proces prawodawczy dwóch dekad - sukcesy i niepowodzenia, „Ruch Prawniczy, Ekonomiczny i Socjologiczny” 2009, nr 2, s. 111.

12 Wymienić tu można na przykład następujące prace: M. Paździora, M. Stambulski, op. cit., s. 57-58; R. Mańko, op. cit., s. 68-69; J. Łakomy, Polityczność (teorii) wyktadni prawa. Perspektywa neopragmatyzmu Stanleya Fisha, „Archiwum Filozofii Prawa i Filozofii Społecznej” 2018, nr 3, s. 24-25.

13 Ch. Mouffe, Polityczność, Warszawa 2008, s. 24.

14 Ibidem.

15 M. Paździora, M. Stambulski, op. cit., s. 57-58. 
Wyjaśnienia wymaga także sposób rozumienia „legislatora” („legislatorów”) przyjęty w poniższych rozważaniach. W literaturze przedstawiono co najmniej dwa sposoby pojmowania „legislatora”. Według Radosława Iłowieckiego

[1]egislator jest pracownikiem aparatu państwowego i zatrudniony jest w parlamentarnych bądź rządowych ośrodkach władzy państwowej, które uprawnione są do wydawania aktów prawnych. W zależności od miejsca pracy jego status reguluje ustawa o pracownikach urzędów państwowych lub ustawa o służbie cywilnej ${ }^{16}$.

\section{Z kolei zdaniem Wiesława Staśkiewicza}

legislator to pracownik aparatu państwowego zatrudniony w administracji rządowej, parlamentarnej lub prezydenckiej, który jest uprawniony do sporządzania projektów aktów normatywnych, ich oceny lub redakcji. Definicja ta nie uwzględnia jednak urzędników pracujących w administracji samorządowej, których zadaniem jest opracowywanie aktów normatywnych prawa miejscowego, oraz grupy prawników, których możemy nazwać legislatorami prywatnymi, ponieważ nie są oni zatrudnieni ani w administracji rządowej, organach centralnych, ani też w administracji samorządowej ${ }^{17}$.

Oba zaproponowane ujęcia „legislatora” uzupełniają się, gdyż Iłowiecki trafnie zwraca uwagę na różnicę normatywną będącą nie tylko podstawą wykonywania zawodu, lecz także różnicą w zakresie swobody podczas wywiązywania się z obowiązków legislatorskich ${ }^{18}$, natomiast Staśkiewicz wprowadza dystynkcję między legislatorami publicznymi a prywatnymi. Ponadto ujęcie Staśkiewicza pozwala w ramach grupy „legislatorów publicznych” wydzielić „legislatorów publicznych centralnych" (rządowych, parlamentarnych, prezydenckich) i „legislatorów publicznych samorządowych". Ta ostatnia grupa, jako równie niejednorodna co legislatorzy prywatni, nie stanowi, podobnie jak legislatorzy prywatni, przedmiotu rozważań zawartych w niniejszym opracowaniu. Zdając sobie sprawę z wielu różnic dzielących na przykład legislatorów rządowych i senackich, możliwe jest odnoszenie spostrzeżeń i wywodów zamieszczonych w tym artykule do legislatorów publicznych centralnych.

\section{LEGISLATOR A PRAWODAWCA W KONTEKŚCIE ZJAWISKA POLITYCZNOŚCI}

Z uwagi na wzmiankowane wcześniej oddziaływania oraz skutki prawne i polityczne procesu tworzenia prawa próba określenia kształtowania statusu i roli legislatorów w tym procesie przez zjawisko polityczności skłania do zadania pyta-

16 R. Iłowiecki, Status legislatora w organach władzy publicznej. Zawód legislator, „Przegląd Sejmowy" 2010, nr 6, s. 28-29.

17 W. Staśkiewicz, Społeczne role legislatora, [w:] Legislacja czasu przemian, przemiany w legislacji. Księga jubileuszowa na XX-lecie Polskiego Towarzystwa Legislacji, red. M. Kłodawski, A. Witorska, M. Lachowski, Warszawa 2016, s. 117.

18 Zob. przyp. 44. 
nia o umiejscowienie legislatorów w konstrukcie prawodawcy ${ }^{19}$, i to prawodawcy faktycznego. Weryfikacji wymaga przy tym intuicja, że inkludowanie legislatorów do konstruktu prawodawcy faktycznego bądź ich ekskludowanie z niego rzutuje na natężenie, kierunek czy wręcz samo istnienie uwarunkowanych politycznością sił towarzyszących procesowi legislacyjnemu.

Prawodawca faktyczny jest definiowany jako „zespół ludzi, którzy biorą udział w procesie ustawodawczym, ludzi faktycznie wywierających wpływ na decyzję prawotwórczą" ${ }^{20}$. Definicja ta jest wystarczająco pojemna, aby objąć osoby zarówno działające jako przedstawiciele formalnie wyposażonych w kompetencję prawodawcą podmiotów instytucjonalnych, jak i działające w strukturach służb legislacyjnych wspierających wspomnianych przedstawicieli w podjęciu optymalnej decyzji prawodawczej. Z tego względu opisywane podejście umożliwia inkludowanie legislatorów do konstruktu prawodawcy faktycznego. Jako akcentujące zróżnicowany komponent personalny łączące się ze wspomnianym podejściem rozumienie prawodawcy faktycznego zyskało w literaturze miano socjologicznego ${ }^{21}$.

Możliwość zakwalifikowania legislatorów do konstruktu prawodawcy faktycznego została zredukowana w zaproponowanym dziesięć lat później ujęciu, zgodnie z którym

prawodawca faktyczny jest instytucjonalnym ciałem kolegialnym, wyposażonym przez normy danego systemu w moc podejmowania finalnych decyzji prawodawczych lub uczestniczenia w przygotowywaniu decyzji tego rodzaju. Substratem owego ciała kolegialnego są zazwyczaj zbiory indywiduów ludzkich, chociaż ciało to nie jest $\mathrm{z}$ danym zbiorem ludzi identyczne ${ }^{22}$.

Czynnikiem utrudniającym inkluzję legislatorów do konstruktu prawodawcy faktycznego jest tutaj uwzględnienie nie tylko komponentu personalnego, lecz także kompetencyjnego. Innymi słowy dodanie perspektywy dogmatycznej do socjologicznej uniemożliwia uznanie legislatorów za podmioty należące do kategorii prawodawcy faktycznego, ponieważ to nie im konwencjonalnie przypisuje się wytwór działalności prawodawczej. Nie są ani organem władzy publicznej wyposażonym w kompetencje do stanowienia przepisów prawa, ani nawet piastunami takich organów.

19 Na temat wielości sposobów rozumienia tego konstruktu, jego rangi w procesie wykładni i tworzenia prawa powstały w literaturze przedmiotu liczne opracowania. Niniejszy artykuł nie przejmuje towarzyszącego wielu z nich zamiaru ustalenia relacji między pojęciem prawodawcy racjonalnego a prawodawcy faktycznego czy też chęci zdefiniowania tych pojęć i skupia się jedynie na przybliżeniu rozumienia prawodawcy faktycznego, ponieważ to właśnie ten drugi prawodawca jest przedmiotem zainteresowania polityczności.

20 E. Kustra, Racjonalny ustawodawca. Analiza teoretycznoprawna, Torun 1980, s. 38.

${ }^{21}$ Zob. S. Wronkowska, Prawodawca racjonalny jako wzór dla prawodawcy faktycznego, [w:] Szkice z teorii prawa i szczegółowych nauk prawnych, red. S. Wronkowska, M. Zieliński, Poznań 1990, s. 118.

22 Ibidem, s. 118-119. 
Dotychczasowe prace z zakresu prawoznawstwa podejmujące, choćby incydentalnie, próbę określenia relacji między konstruktem prawodawcy faktycznego a legislatorami odzwierciedlają zarysowane ograniczenia kwalifikacyjne wyłaniające się z definicji prawodawcy faktycznego przedstawionej przez Sławomirę Wronkowską. Stwierdza się bowiem, że „,[p]race redakcyjne wykonywane przez legislatorów mają odmienny, techniczno-legislacyjny charakter w przeciwieństwie do koncepcyjnych i normotwórczych obowiązków spoczywających na prawodawcy"23. Przemieszanie tych ról niektórzy autorzy wprost traktują jako niepożądane zjawisko ${ }^{24}$. Jednocześnie dostrzega się, że pomimo braku przynależności merytorycznego kształtowania zawartości aktów prawnych do zadań legislatorów rzeczywistą rolę tych ostatnich wyznaczają „oczekiwania decydentów politycznych i istniejąca praktyka”25.

Nieco odmienne stanowisko, upatrujące w legislatorach bardziej równorzędnego — z racji możliwości rozłącznego podziału rolowego na tworzących tekst i uchwalających go (nadających mu moc tekstu aktu prawnego) - partnera prawodawcy faktycznego w procesie legislacyjnym, przedstawia Marcin Matczak. Analizując problematykę złożoności intencji prawodawczej i jej przydatności w interpretacji prawniczej oraz zastanawiając się na rzeczywistym obrazem funkcjonowania legislatywy, badacz ten stwierdza, że odróżnienie intencji twórcy tekstu i intencji osoby dokonującej aktu tekstu jest nieodzowne wtedy, gdy autor tekstu i podmiot posługujący się tekstem są różnymi osobami ${ }^{26}$. Według niego

[z] takim przypadkiem mamy najczęściej do czynienia we współczesnym procesie tworzenia prawa, kiedy techniczne przygotowanie tekstu aktu prawnego powierza się grupie specjalistów-legislatorów wyszkolonych w zakresie sporządzania projektów legislacyjnych. [...] Aktu uchwalenia ustawy dokonuje inna grupa osób niż autorzy tekstu. Najczęściej rolę uchwalających gra grupa parlamentarzystów, która wprawdzie może wziąć udział w tworzeniu tekstu [...], nie jest to jednak warunek niezbędny, aby akt uchwalenia był skuteczny ${ }^{27}$.

Zwłaszcza ostatnie zdanie cytowanego fragmentu pracy Matczaka prowadzi do wniosku, że dopiero analizowanie działalności prawodawcy faktycznego jednocześnie $\mathrm{z}$ analizą czynności podejmowanych przez legislatorów prowadzi do odsłonięcia tego, jak funkcjonuje system tworzenia prawa i jak doniosła może się w nim okazać rola legislatorów.

Co istotne, Matczak nie utożsamia prawodawcy faktycznego z legislatorami. „Osoby te nie grają jednej roli prawodawcy, rozumianego jako mówca. Przeciwnie, grają różne role w procesie tworzenia prawa" ${ }^{28}$. Zauważa jednak,

${ }^{23}$ M. Kłodawski, Redundancja w tekśsie prawnym, Toruń 2017, s. 19-20.

${ }^{24}$ Zob. M. Zubik, Jak poprawić polska legislację, [w:] Jak poprawić rzadzenie Polska w XXI wieku? V Kongres Obywatelski, red. J. Szomburg, Gdańsk 2010, s. 14.

25 A. Bielska-Brodziak, op. cit., s. 244.

${ }^{26}$ M. Matczak, Imperium tekstu. Prawo jako postulowanie i urzeczywistnianie świata możliwego, Warszawa 2019, s. 69.

27 Ibidem.

28 Ibidem, s. 70. 
powołując się na pracę Yona Maleya, że prawodawca i legislatorzy występują po stronie nadawcy, czyli kategorii komunikacyjnej, w której Maley wyróżnia projektującego i źródło, przy czym projektującym może być członek legislatywy lub legislator, a źródłem - legislatywa ${ }^{29}$. Tym samym dotychczasowe perspektywy: dogmatyczna i socjologiczna, $\mathrm{z}$ których analizowano relację prawodawcy i legislatorów, zostają dopełnione komunikacyjnym punktem widzenia. Choć nie ma tu mowy o „rozdwojeniu” prawodawcy faktycznego, „scalonego” dzięki definicji Wronkowskiej, to rozszerzenie pola namysłu ukazuje istnienie pewnej dwoistości nadawcy komunikatów prawodawczych. Nawet jeżeli jest ona tylko potencjalna ${ }^{30}$, to, przyjmując taki stan rzeczy, jako jego naturalna konsekwencja jawi się pytanie o istnienie relacji między prawodawcą faktycznym a legislatorami, liczbę tych relacji oraz stopień ich złożoności. Takie interferencje między legislatorami a prawodawcą faktycznym będą przedmiotem bardziej pogłębionej analizy w dalszej części niniejszego opracowania.

\section{LEGISLATORZY I POLITYCZNOŚĆ — INTERAKCJE}

Niezaliczenie legislatorów do konstruktu prawodawcy faktycznego sprawia, że w procesie tworzenia prawa stopień ich upodmiotowienia jest relatywnie niewielki. Choć trudno wyrażać kategoryczne roszczenie o silniejszą pozycję legislatorów z racji niewyposażenia ich w kompetencję do stanowienia prawa, to niewątpliwie obecna pozycja legislatorów już prima facie wyznacza ich specyficzne relacje z formalnie umocowanymi aktorami procesu legislacyjnego. Połączenie wysokich oczekiwań wobec jakości pracy legislatorów, równie wysokich wymagań w zakresie wykształcenia i posiadanych umiejętności językowo-logiczno-prawnych ${ }^{31}$ ze stosunkowo niewielką mocą (choć nie zawsze ${ }^{32}$ ) wywierania potencjalnego wpływu na warstwę normatyw-

29 Y. Maley, The language of legislation, „Language in Society” 16, 1987, nr 1, s. 31-32.

${ }^{30}$ Zrealizuje się, gdy prawodawca faktyczny nie zaingeruje w treść projektu przygotowanego przez legislatorów. Taki przypadek jest trudny do wyobrażenia podczas procesu ustawodawczego, natomiast można go uznać za dość prawdopodobny w razie na przykład wydania przez ministra rozporządzenia o technicznym lub obliczeniowym, to jest zawierającym wzory, charakterze. Skomplikowanie materii aktu normatywnego aktualizuje wówczas możliwość powstrzymania się prawodawcy faktycznego od ingerencji w treść projektu przygotowanego przez grono legislatorów mających zarazem fachową wiedzę w dziedzinie, której dotyczy rozporządzenie, co zdarza się stosunkowo często w ministerstwach.

31 Por. A. Bielska-Brodziak, op. cit., s. 244. Zob. też S. Wronkowska, Aplikacja legislacyj$n a$, [w:] Leges ab omnibus intellegi debent. Ksiega XV-lecia Rządowego Centrum Legislacji, red. W. Brzozowski, A. Krzywoń, Warszawa 2015, s. 56.

32 Przykładowo można wskazać na art. 70 ust. 1 Regulaminu Sejmu (uchwała Sejmu Rzeczypospolitej Polskiej z dnia 30 lipca 1992 roku, M.P. z 2019 r. poz. 1028) oferujący „służbom prawnym Kancelarii Sejmu możliwość samodzielnego zgłaszania poprawek nie merytorycznych" (A. Bielska-Brodziak, op. cit., s. 220). Zestawiając to z problematyką odróżniania takich poprawek od tych merytorycznych, zarówno jeszcze na etapie tworzenia prawa, jak i później, podczas wykładni (ibi- 
ną tekstu prawnego ${ }^{33}$ sprzyja powstawaniu wrażenia, że wyposażony w odpowiednie zdolności argumentacyjne i perswazyjne legislator jest w stanie przekonać reprezentantów prawodawcy formalnego (na przykład posłów, senatorów, ministrów) do rozwiązania prawnego zaproponowanego $\mathrm{w}$ przygotowanej przez siebie opinii czy projekcie poprawki. Tym samym indywidualne cechy oferują możliwości odparcia sił wywierających nacisk $w$ ramach zjawiska polityczności. Jest to jednak tylko namiastka potencjału, w żaden sposób niezbliżająca legislatora do reprezentantów prawodawcy formalnego, gdyż ostatecznie to sposób instytucjonalnego umocowania legislatora w strukturze aparatu prawodawczego przesądza o tym, do kogo należy decydujący głos czy choćby wola zainicjowania pogłębionej współpracy nad projektem.

Powoduje to, że legislator nie ma obecnie prawnych i formalnych możliwości przeciwstawienia się wykorzystywaniu rezultatów jego pracy jako podpory faworyzującej rozwiązanie, które nie zostało wyraźnie zakwestionowane przez legislatora w toku wykonywania jego obowiązków zawodowych. Nie może także zakwestionować przejawów postponowania przedstawionej przez siebie opinii czy zgłoszonego projektu poprawki. Tym samym skuteczne stawienie oporu, a zwłaszcza wyrażenie niezgody wobec umiejscowienia po którejś stronie sporu w ramach polityczności nie jest możliwe. Legislator ostatecznie staje się biernym uczestnikiem w procesie ścierania się opozycyjnych sił znacznie przeważających nad nim decyzyjnie. Dlatego nawet jego ewentualna „dworskość” 34 nie powinna stawać się zarzutem kierowanym przeciwko całej profesji legislatorskiej. Jeżeli tylko decydent — jako uwikłany w polityczność zleceniodawca opinii i projektu poprawki albo przynajmniej ingerujący w treści tych materiałów - oczekuje od legislatora wysłowienia pewnego punktu widzenia z jakiegoś względu cennego dla frakcji, na rzecz której podejmuje działania wspomniany decydent, albo instrumentalnie dobiera pozbawione kontekstu sformułowanie myśli wyrażonej przez legislatora podczas pracy nad innym projektem aktu normatywnego, to niejako automatycznie następuje wpisanie legislatora do jednego ze spolaryzowanych stronnictw ${ }^{35}$. Legislator w takim przypadku zawsze będzie mógł zostać obciążony mianem „eksperta usłużnego"36, jednak bez pejora-

dem, s. 218-228), zauważalna staje się ewentualna możliwość wpływania przez legislatorów na brzmienie przepisów prawnych w sposób pozwalający modyfikować treść normy odtwarzanej z takiego przepisu.

${ }^{33}$ Legislatorzy ,[b]yli i są bardziej wykonawcami poleceń niż twórcami ustaw, gdyż taką rolę wyznacza im funkcjonujący w Polsce model tworzenia prawa. Legislatorzy zostali zepchnięci do roli techników prawnych zapisujących czyjeś pomysły" - W. Staśkiewicz, op. cit., s. 138.

34 Ekspert „dworski” to taki, który jest powoływany przede wszystkim po to, „by podjętą decyzję przekonywająco uzasadnić, a nie by dostarczyć przesłanek intelektualnych dla jej powzięcia" S. Wronkowska, Ekspert a proces tworzenia prawa, „Państwo i Prawo” 2000, nr 9, s. 12.

35 Jako dostarczyciela uzasadnienia podjętej przez to stronnictwo decyzji, a rzadziej przesłanek za nią stojących czy jej objaśnień.

${ }^{36}$ Zob. S. Wronkowska, Ekspert..., s. 13. 
tywnej konotacji „usłużności”37. Chodzi tu bowiem wyłącznie o „usłużność” rozumianą jako świadczenie usług na rzecz podmiotu o randze nadrzędnej i zwierzchniej, od którego legislator pozostaje zależny. Rezygnacja z tak pojmowanej „usłużności” przez legislatora byłaby zatem równoznaczna z zanegowaniem jego konieczności wykonywania obowiązków służbowych, a w konsekwencji z wysoce prawdopodobną zmianą statusu zawodowego, to jest utratą możliwości dalszego wykonywania swojej pracy, przynajmniej na rzecz dotychczasowego podmiotu, w szerokim rozumieniu przełożonego. Dlatego też trafniejsza wydaje się charakterystyka legislatora jako „usługodawcy”38, a nie jako „usługującego" 39 .

\section{ZMAGANIA Z POLITYCZNOŚCIĄ - DIAGNOZA MECHANIZMÓW OBRONNYCH LEGISLATORÓW I PRZYCZYN NIEDOBORU TYCH MECHANIZMÓW}

Istniejący stan normatywny pozwala legislatorom powoływać się na trwałe filary wiedzy i reguł, których legislator nie może lekceważyć i z których nie może zrezygnować w swym ,starciu” z decydentem. Do tego zasobu źródel ${ }^{40}$ zaliczają się Konstytucja RP ${ }^{41}$, ustawa z dnia 20 lipca 2000 roku o ogłaszaniu aktów normatywnych i niektórych innych aktów prawnych ${ }^{42}$ oraz załącznik do rozporządzenia Prezesa Rady Ministrów z dnia 20 czerwca 2002 roku w sprawie „Zasad techniki prawodawczej”"43. Ten zbiór często okazuje się jednak niewystarczający i to nie tylko wtedy, gdy to mniej doświadczony legislator zmaga się z siłami polityczności ${ }^{44}$. Nietrudno sobie wyobrazić rozwiązanie nienaruszające wymogów i zasad wywo-

37 Ta pejoratywna konotacja może jednak towarzyszyć przypadkowi, w którym byłaby mowa o „usłużności” legislatora prywatnego, to jest działającego poza strukturą publicznych służb legislacyjnych.

38 Por. hasło „usługodawca” w Stowniku języka polskiego pod redakcją W. Doroszewskiego, https://sjp.pwn.pl/doroszewski/uslugodawca;5512551.html (dostęp: 17.02.2020).

39 Por. hasło ,usługujący” w Słowniku języka polskiego pod redakcją W. Doroszewskiego, https://sjp.pwn.pl/doroszewski/uslugujacy;5512556.html (dostęp: 17.02.2020).

$40 \mathrm{~W}$ literaturze zwraca się uwagę na możliwość, a niekiedy wręcz potrzebę wzbogacenia tego zasobu o tak zwaną ustawę o tworzeniu prawa. Ten wątek był żywiołowo dyskutowany w polskim prawoznawstwie w latach siedemdziesiątych i osiemdziesiątych XX wieku, co znalazło odzwierciedlenie w kilku przygotowanych ówcześnie projektach takiej ustawy; zob. S. Wronkowska, Z historii ustawy o tworzeniu prawa, [w:] Legislacja czasu przemian..., s. 210-222. Żaden z projektów nie przybrał jednak postaci obowiązującego prawa — ibidem, s. 221.

${ }^{41}$ Dz.U. z 1997 r. Nr 78, poz. 483 z późn. zm.

42 Dz.U. z 2019 r. poz. 1461.

43 Dz.U. z 2016 r. poz. 283 (dalej: ZTP).

44 Szczególnym przypadkiem jest legislator-członek korpusu służby cywilnej, który zgodnie z art. 77 ustawy z dnia 21 listopada 2008 roku o służbie cywilnej (Dz.U. z 2020 r. poz. 265) jest obowiązany wykonywać polecenia służbowe przełożonych nawet wtedy, gdy są one niezgodne z prawem albo zawierają znamiona pomyłki. W takim przypadku informuje wprawdzie o tym przełożonego, ale 
dzonych z wskazanych aktów normatywnych, ale wyrafinowanie faworyzujące interes podmiotu, któremu „sprzyja” dany decydent - na przykład poprzez usunięcie mechanizmu albo instrumentu prawnego, którego korzystność dla „wybrańca" jest wątpliwa, albo przesunięcie w czasie określonych obowiązków mających ciążyć na tym podmiocie. $Z$ tego względu można mówić o niedoborze narzędzi, którymi może posłużyć się legislator, aby zatrzymać albo przynajmniej spowolnić machinę polityczności.

Na niedostatek zdolności „obronnych” legislatora osłabiających możliwości niwelowania sił polityczności wpływają co najmniej trzy okoliczności. Pierwszą z nich jest nieunormowanie statusu zawodowego legislatora i dookreślenia specyfiki tej profesji, włącznie z rodzajem zadań, którymi można obarczyć legislatora w procesie prawodawczym, i charakterem obowiązków spoczywających w tym procesie na legislatorach. Drugą, pozostającą w ścisłym związku z pierwszą, jest utrzymujące się nieuregulowanie zasad etyki legislatorskiej, do której przestrzegania obowiązane byłyby osoby wykonujące zadania legislatora i na które mogłyby się powołać w razie chęci instrumentalnego zaangażowania przez decydentów. Trzecią jest sposób organizacji procesu prawodawczego, obfitujący w różnie motywowane rozwiązania doraźne, zwłaszcza wobec niewystępowania tych planowych.

Pierwsza z podniesionych kwestii może być analizowana pod względem treściowym, dotyczącym rodzaju zadań legislatora, i formalnym, związanym ze sformułowaniem oraz utrwaleniem reguł zdobywania i wykonywania tego zawodu. W aspekcie treściowym na gruncie polskiego systemu stanowienia prawa wciąż aktualne pozostaje stwierdzenie, że ,,[n]ie rozstrzygnięto [...] podstawowego dylematu, czy legislator ma być wyłącznie redaktorem, czy również doradcą prawodawcy. Zadania legislatorów są nadal przedmiotem sporów"45. Wskazuje się jednak, że nie zawsze takie ścisłe rozróżnienie typu zadań jest możliwe, ponieważ zadania zależą od rodzaju procesu prawodawczego oraz jego etapu ${ }^{46}$. Dlatego też

w praktyce legislator „tylko” piszący lub poprawiający tekst z konieczności odgrywa także rolę doradcy dostarczającego wiedzy o dotychczasowym stanie unormowania danej dziedziny, o dopuszczalności zastosowania określonych środków prawnych i o prawdopodobnych skutkach takiego, a nie innego sformułowania tekstu. Rolę tę należycie może wypełniać jedynie w dialogu z tym, kto podejmuje decyzje merytoryczne ${ }^{47}$.

Taka konfuzja i mieszanie ról wydają się akceptowalne jedynie przy założeniu, że legislator zostanie uznany tylko za doradcę ${ }^{48}$, a nie również za tak zwanego eksperta, gdyż efekty i parametry działalności tego ostatniego w procesie legislacyjnym

po otrzymaniu pisemnego potwierdzenia polecenia jest obowiązany je wykonać. Wyłączone jest tylko wykonywanie poleceń, których wykonanie prowadziłoby do popełnienia przestępstwa lub wykroczenia.

45 W. Staśkiewicz, op. cit., s. 127.

46 S. Wronkowska, Aplikacja..., s. 56.

47 Ibidem, s. 55.

48 Zob. J. Zajadło, Etyka doradcy prawnego władz publicznych (na przykładzie afery tzw. Torture Papers), „Przegląd Sejmowy” 2007, nr 6, s. 243. 
odgrywają w mechanizmach polityczności jeszcze większą rolę niż w przypadku aktywności legislatora ${ }^{49}$, i to mimo istotnych co do tego wątpliwości ${ }^{50}$. Precyzyjnej demarkacji pomagającej ustalić, kiedy legislator jest tylko redaktorem, a kiedy także doradcą, brakuje również z powodu możliwych napięć występujących na styku profesji legislatora i eksperta ${ }^{51}$.

$\mathrm{Z}$ istniejącego braku unormowań i swoistego nieładu w omawianych kwestiach skwapliwie korzystają decydenci polityczni, którzy jako piastuni organów władzy prawodawczej utrzymują status quo, a ponadto pozostawiają otwartą odpowiedź na pytanie o potrzebę i stopień sformalizowania dróg dojścia do wykonywania zawodu legislatora. Przedstawiane są dwie alternatywne ścieżki — zawodu „rynkowego"52 albo zawodu zaufania publicznego ${ }^{53}$, z jednoczesnym dostrzeżeniem trudności wiążących się z dokonaniem wyboru i jego wyrażeniem w prawie ${ }^{54}$. Powstrzymywanie się od jednoznacznego opowiedzenia się przez prawodawcę formalnego po którejś ze stron sprawia, że ,zawód legislatora stał się bardziej kategorią umowną niż prawną (z wyjątkiem osób zatrudnionych w urzędach państwowych), bardziej regulowaną zwyczajowo niż oficjalnie" 55 . Tam zaś, gdzie nie funkcjonuje prawo, działa polityczność, która korzysta na braku regulacji i w mniej skrępowany sposób obciąża legislatorów zadaniami, które do nich nominalnie nie należą. Niewłaściwe jest jednak przyjmowanie, że skoro legislatorzy pozostają w ścisłej, bliskiej współpracy z prawodawcą faktycznym, to celowe jest pozostawienie jemu, a nie regułom prawnym czy wewnętrznym (samorządowym, korporacyjnym), możliwości doraźnego pozaprawnego kształtowania statusu i roli legislatorów, ponieważ takie rozwiązanie dopuszcza potencjalne postawienie wspomnianych już zarzutów „usłużności” i „dworskości”. Nawet normy prawa pracy — obowiązujące legislatora pozostającego w stosunku pracy — trudno przy tym uznać za gwarancję istnienia nieprzekraczalnego katalogu obowiązków zawodowych legislatora, gdyż są one wystarczająco elastyczne, by pomieścić również przypadki wymagające od działających dla dobra szeroko pojętego interesu publicznego legislatorów natychmiastowej sprawności w analizie kilkudziesięciu skomplikowanych treściowo, systemowo i redakcyjnie przepisów prawnych ${ }^{56}$.

49 Zob. C. Kosikowski, Rola organów opiniodawczych i ekspertów w tworzeniu prawa podatkowego w Polsce, „Przegląd Legislacyjny” 2005, nr 1, s. 14.

50 Na przykład A. Bielska-Brodziak zwraca uwagę na problem nieistnienia mechanizmów weryfikacji jakości wiedzy fachowej eksperta i jego kompetencji w zakresie opinii zleconej do wykonania poza Biurem Analiz Sejmowych; zob. eadem, op. cit., s. 281.

51 W. Staśkiewicz, op. cit., s. 135. Zob. też S. Wronkowska, Ekspert..., s. 11 n.

52 Por. W. Staśkiewicz, op. cit., s. 138.

53 R. Iłowiecki, op. cit., s. 35-44, zwł. s. 36-37.

54 Por. W. Staśkiewicz, op. cit., s. 131.

55 Ibidem.

56 Najlepiej jest to widoczne na przykład wtedy, gdy podczas dyżuru legislatora senackiego w trakcie obrad Senatu na posiedzeniu senator, działając na podstawie art. 44 ust. 3 Regulaminu Senatu (uchwała Senatu Rzeczypospolitej Polskiej z dnia 23 listopada 1990 roku, M.P. z 2018 r. poz. 846), 
Równie aktualna jest problematyka etyki legislatorów, w której brakuje rozstrzygnięć umożliwiających określenie zasad odpowiedzialności zawodowej legislatorów oraz ich relacji do organów władzy prawodawczej, jak również do piastunów tych organów, lobbystów i ekspertów uczestniczących w procesie tworzenia prawa. Choć nie budzi wątpliwości, że „,[e]tyka zawodowa legislatora powinna opierać się na takich wartościach, jak silny charakter, wewnętrzna uczciwość, dbanie o godność osobistą i urzędu, wysoki profesjonalizm"57 oraz że ewentualny legislatorski ,[k]odeks etyki powinien zawierać postanowienia o bezpartyjności legislatora oraz zakazywać łączenia niektórych stanowisk" 58 , to już wypracowanie jednego modelu etyki legislatorskiej uwzględniającego te wartości i założenia nastręcza poważnych trudności.

W literaturze przedstawiono co najmniej cztery modele etyki legislatora, zaznaczając wyraźnie, że są one wobec siebie alternatywne, a każdy kolejno zaprezentowany ma być odpowiedzią na słabości poprzednich ${ }^{59}$. Z przeglądu zaproponowanych modeli etyki ${ }^{60}$ wyraźnie widać, że sama polityczność lub podbudowane nią uwarunkowania instytucjonalne procesu legislacyjnego są współcześnie przeszkodami w wyborze wizji etyki legislatora mogącej lec u podstaw szczegółowych rozwiązań utrwalających bądź konstytuujących zasady etyki legislatora. Te ostatnie mogłyby jednak zdecydowanie osłabić działanie sił i mechanizmów polityczności wpływających na status i rolę legislatorów. Potrzebne byłoby więc uformowanie stabilnego zbioru norm deontologicznych uwzględniającego atrybuty zawodu legislatora przy zachowaniu świadomości co do istnienia trudności związanych z takim przedsięwzięciem.

Ostatnim polem, które daje nadzieję na wzrost zdolności „obronnych” legislatora przed skutkami polityczności, jest sposób organizacji procesu prawodawczego. Występowanie (albo nieobecność) niektórych etapów i cech procedury tworzenia prawa może determinować zakres obowiązków i zadań spoczywających na legislatorach, co — jak argumentowano wcześniej — ściśle łączy się z problematyką przesiąkniętych politycznością relacji między legislatywą i jej członkami a legislatorami. Analizując ten wątek bez drobiazgowego wnikania w odrębności i specyfikę poszczególnych stadiów procesu prawodawczego, można dostrzec, że wśród etapów tego procesu trudno odnaleźć etap planowania legislacyjnego oraz etap porządkowania prawa, związany z jego okresowym przeglądem.

Planowanie legislacyjne, rozumiane jako niezależne od bieżącej polityki partyjnej zapewnianie i wskazywanie w perspektywie czasowej przekraczającej okres

składa wniosek o charakterze legislacyjnym, zawierający liczne poprawki sprowadzające się do dodania lub zmiany takich przepisów, a zarazem niedostosowany do aktualnego i przyszłego (na dzień wejścia w życie procedowanej ustawy) stanu prawnego.

57 R. Iłowiecki, op. cit., s. 45-46.

58 Ibidem, s. 46.

59 P. Skuczyński, Etyka legislatora a racjonalne tworzenie prawa, [w:] Leges ab omnibus..., s. 459.

${ }^{60}$ Ibidem, s. 449-459. 
kadencji organów władzy prawodawczej obszarów tematycznych wymagających rozważenia interwencji regulacyjnej w drodze stanowienia przepisów prawnych, jest w polskim systemie tworzenia prawa nieznane. Dotyczy to prawodawstwa na poziomie rządowym i parlamentarnym. Dlatego też ,z uwagi na brak planów legislacyjnych parlamentarny proces legislacyjny jest procesem żywiołowym, w efekcie wyjątkowo podatnym na wpływy polityków, grup interesów i lobbystów. Stawia to na porządku dziennym problem niezależności i neutralności legislatorów”61. Problem ten dotyka również etapu rządowego procedury prawodawczej, ponieważ wymogu planowania legislacyjnego nie spełniają wykazy rządowych projektów ustaw, które są publikowane w Biuletynie Informacji Publicznej62.

W polskim systemie stanowienia prawa nie występuje także zjawisko porządkowania prawa. Jak zauważa Staśkiewicz, nie dochodzi do

przeglądu ustawodawstwa pod kątem jego spójności, niesprzeczności i racjonalności w zmieniających się warunkach społeczno-gospodarczych. [...] Myślenie o potrzebie przeglądu i ocenie polskiego systemu nie tylko pod kątem jego funkcjonalności i unifikacji z prawem unijnym, ale także pod kątem wymogów techniki legislacyjnej i koherentności jest obce polskiej kulturze prawnej, co w bezpośredni sposób wyznacza zakres prac polskiego legislatora, do którego nie należą tego rodzaju działania ${ }^{63}$.

Skutkiem rozumianego w taki sposób braku porządkowania prawa i planowania legislacyjnego są częste działania prawodawcze o charakterze doraźnym, takie jak legislacja ad hoc czy pork barrel legislation ${ }^{64}$, w których udział legislatora często odbywa się jedynie z powodu chęci zachowania wymogów formalnych. Jakiekolwiek uwagi czy sugestie legislatora a priori nie będą miały w takich przypadkach przełożenia na brzmienie przepisów zawartych w aktach normatywnych. Można zatem przyjąć, że wówczas polityczność triumfuje w pełni, gdyż skrajnie zaniża status i rolę legislatora w procesie prawodawczym.

\section{UWAGI KOŃCOWE}

W poprzednich częściach artykułu starano się przedstawić argumenty przemawiające za uznaniem, że kategoria polityczności wykazuje przydatność podczas zgłębiania i diagnozowania specyfiki zawodu legislatora. Występujące w procesie stanowienia prawa antagonizmy, jako postawy niezbędne do wystąpienia i obserwacji zjawiska polityczności, nie obejmują legislatorów jako podmiotów uczestniczących w ścieraniu się rozmaitych interesów. Legislator znajduje się jednak w polu zainteresowania polityczności, ale jako byt niemający podmiotowego charakteru, a więc niemogący przeciwstawić się oddziaływaniu polityczności. Le-

\footnotetext{
61 W. Staśkiewicz, op. cit., s. 134.

62 Ibidem, s. 121.

63 Ibidem, s. 122.

${ }^{64} \mathrm{Na}$ temat obu wspomnianych zjawisk zob. ibidem, s. 121-122.
} 
gislator nie jest decydentem, lecz bytem podporządkowanym polityczności i siłom nią rządzącym. Jeżeli powstaje wrażenie, że legislator kształtuje, uzasadnia czy choćby objaśnia jedno ze skonfliktowanych, a przynajmniej opozycyjnych stanowisk prezentowanych przez danego decydenta, to dlatego że działa na polecenie tego ostatniego, który może przy tym wyrażać swój interes, interes partyjny lub interes danej części legislatywy, czyli na przykład samego rządu czy parlamentu. Ta esencjonalna dla zawodu legislatora relacja hierarchiczna sprawia, że ewentualne twierdzenie o „dworskości” legislatora nie może być rozważane jako podbudowa zarzutu nierzetelności czy niefachowości pracy wykonywanej przez danego przedstawiciela tego zawodu, gdyż „dworskość” może stać się cechą każdego legislatora publicznego centralnego, w zależności od powierzonego mu zadania.

Jednocześnie legislatorzy-urzędnicy państwowi mają więcej swobody w swoich analizach niż legislatorzy-członkowie służby cywilnej. W ten sposób na przykład legislator senacki ma prawnie zapewnioną mniejszą podatność na oddziaływania polityczności niż legislator wykonujący swe obowiązki w Kancelarii Prezesa Rady Ministrów, co nie do końca można uzasadnić różnicami w specyfice parlamentarnego i rządowego etapu procesu legislacyjnego. Bez względu jednak na miejsce zatrudnienia legislatorzy nie dysponują mechanizmami pozwalającymi przeciwstawić się decydentom, co wszakże nie usprawiedliwia ewentualnych niedoskonałości i braków podczas wykonywania ich roli zawodowej. Sprzyja temu natomiast brak unormowanego zbioru zasad etyki zawodowej ${ }^{65}$, który dopełniłby obowiązki, o innym wszakże charakterze, wynikające z ZTP i pozaprawnych źródeł techniki prawodawczej ${ }^{66}$. Ponadto czynnikami utrudniającym stawianie oporu politycznym naciskom są niedostatki regulacyjne w zakresie określenia tego, jakim typem zawodu jest legislator, oraz sposób organizacji procesu legislacyjnego.

Z wymienionych względów postulować należy wypracowanie standardu legislacyjnego ${ }^{67}$, w którym wyraźnie zdefiniowana zostanie, i to na wszystkich etapach procesu legislacyjnego, rola legislatorów. Nieistnienie takiego standardu, a tym samym jego spełniania, utrudnia kontrolę wszelkich władczych działań w sferze prawodawstwa, przy których uczestniczą legislatorzy i z których znaczna część wynika z polityczności woli decydentów. Zbudowanie takiego standardu i dążenie do jego maksymalizacji całkowicie wpisuje się w zasadę demokratycznego państwa prawa, a więc zadeklarowanego stanu ustroju polskiego i zarazem postulowanego wzorca dla niego. Oczekiwanie w tym zakresie nadal pozostaje aktualne i dlatego możliwe jest twierdzenie, że w jego ramach idea regulatywna praworządności pozostaje tylko nie w pełni zrealizowaną ideą.

65 Przy jednoczesnym zachowaniu w polu uwagi, że niektórych legislatorów obowiązują normy deontologiczne, na przykład legislatorów będących członkami korpusu służby cywilnej.

${ }^{66}$ Zob. M. Kłodawski, M. Berek, Dobre praktyki legislacyjne jako pozaprawne źródło techniki prawodawczej, „Przegląd Legislacyjny” 2017, nr 3, s. 13.

67 Zob. T. Biernat, Między polityka a prawem. Problem , upolitycznienia” tworzenia prawa, „Przegląd Prawa i Administracji” 110, 2017, s. 127-128. 
Zważywszy na wszystkie poczynione uwagi, jako zasadne jawi się tytułowe twierdzenie o „pułapce polityczności”, w której znaleźli się legislatorzy w Polsce po przemianach ustrojowych z końca lat osiemdziesiątych XX wieku. Wydostając się z roli redaktorów aktów normatywnych i zyskując dodatkowe możliwości działania w obszarze swej profesji, trafili do tego miejsca w systemie stanowienia prawa, w którym widoczne i nieprzemijalne jest oddziaływanie sił polityczności. Problem polega jednak nie na nowej, poszerzonej i wzbogaconej roli w procesie tworzenia aktów normatywnych, sytuującej legislatorów w bliskim towarzystwie prawodawcy faktycznego, lecz na poddaniu ich konieczności zmagania się z siłami, których kierunkowi i natężeniu nie mogą się skutecznie opierać, co w konsekwencji prowadzi do niemożliwości przeciwstawienia się tworzeniu „bubli prawnych"68 i samodzielnego zablokowania „złych projektów” ${ }^{69}$ legislacyjnych. Choć sami legislatorzy nie dążą w żaden sposób do otrzymania tak poważnych kompetencji, to ich przyznanie — w rozsądnym i gruntownie uzasadnionym zakresie — mogłoby być dla legislatorów swoistą rekompensatą za ich trud w ścieraniu się z politycznością, a dla legislacji szansą na poprawę jakości aktów normatywnych.

\section{LEGISLATIVE DRAFTERS IN THE TRAP OF THE POLITICAL}

\section{Summary}

This article delivers an analysis of legislative drafters' status and role through the category of the political, excerpted from the work of Chantal Mouffe. The special point of interest presented in the conducted study is the relationship between legislative drafters and the legislator, influences of the Political on the position and possible actions of legislative drafters during enacting the law and the ability of the legislative drafters' to resist the Political forces included and engaged in the entire legislative process. The Polish system of lawmaking serves as an example that demonstrates which factors and circumstances, having a political origin, entail the construction of a so-called political trap for legislative drafters. The main statement in the paper is that susceptibility of legislative drafters to the impacts of political forces remains beyond their control, contrary to the representatives of the legislator, although legislative drafters are also actors in numerous stages of the creation of the law.

Keywords: legislative drafter, legislative counsel, legislation, lawmaking, the political

\section{BIBLIOGRAFIA}

Bielska-Brodziak A., Śladami prawodawcy faktycznego. Materiały legislacyjne jako narzędzie wykładni prawa, Warszawa 2017.

Biernat T., Między polityka a prawem. Problem , upolitycznienia” tworzenia prawa, „Przegląd Prawa i Administracji” 110, 2017.

68 Por. R. Iłowiecki, op. cit., s. 43.

69 Por. A. Bielska-Brodziak, op. cit., s. 244. 
Borowicz A., Argument interpretacyjny odwolujący się do woli rzeczywistego prawodawcy, „Studia Prawno-Ekonomiczne" 79, 2009.

Iłowiecki R., Status legislatora w organach władzy publicznej. Zawód legislator, „Przegląd Sejmowy" 2010, nr 6.

Kłodawski M., Redundancja w tekście prawnym, Torun 2017.

Kłodawski M., Berek M., Dobre praktyki legislacyjne jako pozaprawne źródło techniki prawodaw$c z e j$, „Przegląd Legislacyjny” 2017, nr 3.

Kosikowski C., Rola organów opiniodawczych i ekspertów w tworzeniu prawa podatkowego w Polsce, „Przegląd Legislacyjny” 2005, nr 1.

Kustra E., Racjonalny ustawodawca. Analiza teoretycznoprawna, Torun 1980.

Łakomy J., Polityczność (teorii) wyktadni prawa. Perspektywa neopragmatyzmu Stanleya Fisha, „Archiwum Filozofii Prawa i Filozofii Społecznej” 2018, nr 3.

Maley Y., The language of legislation, „Language in Society” 16, 1987, nr 1.

Malinowski A., Btędy formalne w tekstach prawnych, Warszawa 2020.

Mańko R., Orzekanie w polu polityczności, „Filozofia Publiczna i Edukacja Demokratyczna” 7, 2018, nr 1 .

Matczak M., Imperium tekstu. Prawo jako postulowanie i urzeczywistnianie świata możliwego, Warszawa 2019.

Mouffe Ch., Polityczność, Warszawa 2008.

Paździora M., Stambulski M., Co może dać nauce prawa polityczność? Przyczynek do przyszłych badań, „Archiwum Filozofii Prawa i Filozofii Społecznej” 2014, nr 1.

Radwański Z., Rola prawników w tworzeniu prawa, „Państwo i Prawo” 1994, nr 3.

Skuczyński P., Etyka legislatora a racjonalne tworzenie prawa, [w:] Leges ab omnibus intellegi debent. Księga XV-lecia Rządowego Centrum Legislacji, red. W. Brzozowski, A. Krzywoń, Warszawa 2015.

Staśkiewicz W., Społeczne role legislatora, [w:] Legislacja czasu przemian, przemiany w legislacji. Ksiega jubileuszowa na XX-lecie Polskiego Towarzystwa Legislacji, red. M. Kłodawski, A. Witorska, M. Lachowski, Warszawa 2016.

Wronkowska S., Aplikacja legislacyjna, [w:] Leges ab omnibus intellegi debent. Księga XV-lecia Rzadowego Centrum Legislacji, red. W. Brzozowski, A. Krzywoń, Warszawa 2015.

Wronkowska S., Ekspert a proces tworzenia prawa, „Państwo i Prawo” 2000, nr 9.

Wronkowska S., Prawodawca racjonalny jako wzór dla prawodawcy faktycznego, [w:] Szkice z teorii prawa i szczegółowych nauk prawnych, red. S. Wronkowska, M. Zieliński, Poznań 1990.

Wronkowska S., Proces prawodawczy dwóch dekad — sukcesy i niepowodzenia, „Ruch Prawniczy, Ekonomiczny i Socjologiczny” 2009, nr 2.

Wronkowska S., Z historii ustawy o tworzeniu prawa, [w:] Legislacja czasu przemian, przemiany w legislacji. Księga jubileuszowa na XX-lecie Polskiego Towarzystwa Legislacji, red. M. Kłodawski, A. Witorska, M. Lachowski, Warszawa 2016.

Wronkowska S., Ziembiński Z., Zarys teorii prawa, Poznań 2001.

Zajadło J., Etyka doradcy prawnego władz publicznych (na przykładzie afery tzw. Torture Papers), „Przegląd Sejmowy” 2007, nr 6.

Zubik M., Jak poprawić polska legislację, [w:] Jak poprawić rządzenie Polska w XXI wieku? V Kongres Obywatelski, red. J. Szomburg, Gdańsk 2010. 